\title{
Mapping of linear antibody epitopes of the glycoprotein of VHSV, a salmonid rhabdovirus
}

\author{
M. Fernandez-Alonso ${ }^{1}$, G. Lorenzo ${ }^{1}$, L. Perez ${ }^{1}$, R. Bullido ${ }^{1}$, A. Estepa ${ }^{1}$, \\ N. Lorenzen ${ }^{2}$, J. M. Coll ${ }^{1, *}$
}

'INIA, Sanidad Animal, CISA - Valdeolmos, E-28130 Madrid, Spain

${ }^{2}$ Danish Veterinary Laboratory, Hangovej 2, DK-8200 Århus N, Denmark

\begin{abstract}
Antibody linear epitopes of the glycoprotein G (gpG) of the viral haemorrhagic septicaemia virus (VHSV), a rhabdovirus of salmonids, were mapped by pepscan using overlapping 15-mer peptides covering the entire gpG sequence and ELISA with polyclonal and monoclonal murine and polyclonal trout. antibodies. Among the regions recognized in the pepscan by the polyclonal antibodies (PAbs) were the previously identified phosphatidylserine binding heptad-repeats (Estepa \& Coll 1996; Virology 216:60-70) and leucocyte stimulating peptides (Lorenzo et al. 1995; Virology 212:348-355). Among 17 monoclonal antibodies (MAbs), only 2 non-neutralizing MAbs, 110 (aa 139-153) and IP1H3 (aa 399-413), could be mapped to specific peptides in the pepscan of the gpG. Mapping of these MAbs was confirmed by immunoblotting with recombinant proteins and/or other synthetic peptides covering those sequences. None of the neutralizing MAbs tested reacted with any of the gpG peptides. Previously mapped MAb resistant mutants in the gpG did not coincide with any of the linear epitopes defined by the pepscan strategy, suggesting the complementarity of the 2 methods for the identification of antibody recognition sites.
\end{abstract}

KEY WORDS: Epitopes - Glycoprotein - VHSV Rhabdovirus

\section{INTRODUCTION}

A subunit vaccine against the viral haemorrhagic septicaemia virus (VHSV) would be most convenient to slow down one of the most damaging diseases in the worldwide salmoniculture industry. Attempts to obtain it, however, have not yet been really successful (Leong et al. 1995, Lorenzen \& Olesen 1997). The viral glycoprotein G (gpG) elicits neutralizing antibodies and has also been shown to be an efficient stimulator of leucocyte proliferation in vitro (Estepa et al. 1994, Lorenzo et al. 1995). As the gpG appears to activate humoral as well as cellular defense mechanisms, it seems to be an obvious candidate for a recombinant vaccine. However, the recombinant gpG of VHSV conferred no or moderate protection against VHSV by immersion when expressed in bacterial cells such as Escherichia coli (Lorenzen \& Olesen 1997), Aeromonas salmoni-

-Addressee for correspondence. E-mail: coll@inia.es cida (Noonan et al. 1995) or Yersinia ruckeri (Estepa et al. 1994). Furthermore, only moderate protection was obtained by injection of the gpG when expressed in insect cells (Lecocq-Xhonneux et al. 1994) or by immersion on gpG when expressed in yeast (Estepa et al. 1994).

Reduction of the disulfide bonds of the gpG inhibited the binding of many neutralizing monoclonal antibodies (MAbs) to rhabdoviruses such as rabies (Benmansour et al. 1991), vesicular stomatitis virus, VSV (Keil \& Wagner 1989), VHSV (Lorenzen et al. 1990, Bearzotti et al. 1995) and infectious haematopoietic necrosis virus, IHNV (Kim et al. 1994, Huang et al. 1996). Sequencing of MAb neutralization resistant (MAR) mutants of rabies (Benmansour et al. 1991 Raux et al. 1995), VSV (Vandepol et al. 1986, Luo et al. 1988), IHNV (Kim et al. 1994) and VHSV (Bearzotti et al. 1995) has suggested that 2 regions being distant in the primary structure of the gpG might be associated in the native conformational stage of the protein. Only a few linear reduction-resistant neutralization epitopes 
have been identified in rabies (VanDeerHeijden et al. 1993, Ni et al. 1995), VSV (LeFrancois \& Lyles 1982, Volk et al. 1982, Keil \& Wagner 1989, Grigera et al. 1992) and IHNV (Leong et al. 1995) but none yet in VHSV (Lorenzen et al. 1990, Sanz \& Coll 1992). The present study focusses on mapping of linear antibody epitopes on the gpG of VHSV. Because neutralizing ability of an antibody to a rhabdovirus (i.e. VHSV) in cell culture does not always correlate with its protection properties in vivo (LeFrancois 1984) and nonneutralizing anti-VHSV antibodies can be VHS protective when injected in vivo (Lorenzen et al. 1990), the present work is also an attempt to identify some of the major antigenic sites (neutralizing or not neutralizing) that can be mimicked by synthetic peptides in the gpG of VHSV. Mapping of the linear antibody epitopes in the gpG could either give information concerning the failure of recombinant gpG as a vaccine and/or identify regions of the protein which could be important to include in a future vaccine.

\section{MATERIALS AND METHODS}

Synthetic peptides from the gpG sequence of VHSV. A series of 15-mer peptides overlapping 5 amino acids (aa) and spanning the cDNA derived a sequence of the gpG (Thiry et al. 1991) of VHSV 07.71 were chemically synthesized (Chiron Mimotopes, Victoria, Australia). The peptides were named by the amino terminal position of their middle aa (8th position) in the protein sequence, the first peptide of the $g p G$ being the number 6 due to needs of synthesis (it contained 2 additional aa before the initial methionine, according to the cDNA sequence). Additional peptides, p2 (aa 82109), p3 (aa 110-121) and p4 (ad 122-151), were obtained from Clontech (Palo Alto, CA, USA).

Viral haemorrhagic septicaemia virus. The VHSV 07.71 isolated in France (LeBerre et al. 1977) from rainbow trout Oncorhynchus mykiss (Walbaum) was used for most of the experiments. The VHSV was grown and assayed for infectivity in epithelial papillosum cyprini (EPC) cells as described previously (Basurco et al. 1991). For production of purified VHSV, confluent cultures of EPC cells were grown in flasks of $150 \mathrm{~cm}^{2}$ (Costar) and inoculated with 10 plaque forming units (PFU) of VHSV 07.71 per cell. The culture was harvested after 5 to $7 \mathrm{~d}$ at $14^{\circ} \mathrm{C}$ and centrifuged at $12000 \times g$ for $30 \mathrm{~min}$ to remove cell debris. VHSV was precipitated with $7 \%$ polyethyleneglycol (PEG) 6000 in $2.3 \% \mathrm{NaCl}, \mathrm{pH} 7.8$. After overnight agitation at $4{ }^{\circ} \mathrm{C}$, the VHSV was pelleted at $20000 \times g$ for $40 \mathrm{~min}$. The pellet was dissolved in $10 \mathrm{mM}$ Tris, $1 \mathrm{mM}$ EDTA and $100 \mathrm{mM} \mathrm{NaCl}, \mathrm{pH} 7.6$ (TEN) and frozen until used. VHSV concentrated by PEG was layered on a 15 to
$45 \%$ sucrose gradient in TEN and spun at $80000 \times g$ for $270 \mathrm{~min}$ in a Beckman ultracentrifuge. The band containing infectivity at $31 \%$ sucrose (Basurco et al. 1991) was further purified by ultracentrifugation through a $20 \%$ sucrose cushion and kept at $4{ }^{\circ} \mathrm{C}$ for a few weeks until used.

Isolation of soluble gpG by affinity chromatography. Soluble gpG (gpGs) was isolated by affinity chromatography over Sepharose-concanavalin A from VHSVinfected and VHSV-free cell culture supernatants (Perez et al. 1998). The affinity chromatography buffer was $0.1 \mathrm{M}$ sodium acetate adjusted to $\mathrm{pH} 7.6$ to which salts were added to the following final concentrations: $1 \mathrm{mM} \mathrm{MnCl}_{2}, 1 \mathrm{mM} \mathrm{MgCl}, 1 \mathrm{mM} \mathrm{CaCl}_{2}$ and $1 \mathrm{M} \mathrm{NaCl}$. About $2 \mathrm{l}$ of PEG supernatants in affinity chromatography buffer was chromatographied through a ConA column $(1.5 \times 1 \mathrm{~cm})$. Concentrated salts were added to the VHSV-free supernatants to obtain the final concentrations mentioned above. The supernatant was passed more than 8 times through the column with the aid of a peristaltic pump at room temperature. After washing the column with $100 \mathrm{ml}$ of affinity chromatography buffer, the bound gpGs was eluted with $10 \mathrm{ml}$ of $1 \mathrm{M}$ glucopyranoside, $1 \mathrm{M}$ mannopyranoside in chromatography buffer. The gpGs preparations contained $~ 30 \%$ of the molecules as trimers and $70 \%$ as monomers of $\sim 60 \mathrm{kDa}$ as shown by ultracentrifugation in sucrose gradients and by PAGE and immunoblotting.

Recombinant VHSV gpG. Fragment gpG4 (aa 9443) was cloned and expressed in the yeast Saccharomyces cerevisae DC04 as reported previously (Estepa et al. 1994). The nucleotide sequences encoding aa 17-191, 153-474 and 360-474 were amplified by PCR using the cloned G gene of VHSV isolate 3592B as a template following the principles outlined earlier (Lorenzen et al. 1993). The vector used for expression under the control of a $\mathrm{T} 7$ bacteriophage promotor has been described by Christensen et al. (1991). Using the Ndel and HindIII sites downstream of the T 7 promotor, the earlier fusion protein construct including parts of the $\lambda$ cll and myosin light chain genes as fusion partner (Lorenzen et al. 1993) was inserted into the expression vector. Amplified $G$ fragments were subsequently cloned into the vector using the BamH I and Hind III sites of the construct. Expression of the fusion proteins was induced by addition of $\lambda \mathrm{CE}-6$ carrying the T7 polymerase gene, to exponentially growing Escherichia coli DH1 cells when the ODboo was approx. 0.9. Cultivation was continued for another $3 \mathrm{~h}$ and the cells were subsequently harvested by centrifugation. Cell pellets were dissolved by boiling in reducing sample buffer for SDS-PAGE. SDS-PAGE and immunoblotting were performed as before (Lorenzen et al. 1990). Purified virus was used a positive control antigen. 
Monoclonal antibodies (MAbs). MAbs against VHSV 07.71 were produced by immunization of $\mathrm{Balb} / \mathrm{c}$ mice with either recombinant VHSV gpG4 expressed in yeast $(30 \mu \mathrm{g}$ per injection) or with heat-killed whole virus ( $50 \mu \mathrm{g}$ per injection). The final boost was carried out by intravenous injection of purified soluble gpGs protein $(10 \mu \mathrm{g}$ per injection). Spleen cells from immunized mice were fused with the myeloma cell lines SP2 or P3-X63-Ag.653 myeloma line (Sanz et al. 1993). Screening of the hybridoma supernatants was performed by indirect ELISA on gpG4 coated plates and by flow cytometry (FACS) on VHSV-infected EPC cells. Culture supernatants from the selected clones were concentrated by ammonium sulfate precipitation or purified by protein A-Sepharose (Pharmacia) following methods described before (Sanz et al. 1993). The concentrated samples were applied onto precoated nitrocellulose membrane strips (ImmunoType Kit, Sigma) to determine the MAbs isotypes by following the procedure recommended by the manufacturers of the kit. Other MAbs used were $3 \mathrm{~F} 1 \mathrm{H} 10$ and $\mathrm{IP} 1 \mathrm{H} 3$ (Lorenzen et al. 1990) and I10 kindly donated by Dr De Kinkelin (Mourton et al. 1990). Neutralizing MAb C10 was obtained from Sanofi Diagnostic Pasteur (MarnesLa-Coquette, France). Neutralizing MAb 3F1A2 (Lorenzen et al. unpubl.) was produced as described earlier (Lorenzen et al. 1990). 1H10 is a neutralizingenhancing MAb that recognized the denatured form of the gpG (Sanz \& Coll 1992). The ability of the MAbs to react with a denatured form of VHSV gpG was tested by Western blot analysis. SDS-acrylamide $12 \%$ gels were loaded with $1 \mathrm{mg}$ gpG4 in buffer containing mercaptoethanol. The proteins in the gel were transferred to nitrocellulose membranes (BioRad). The membranes were blocked with $2 \%$ dry milk, 0.05 Tween- 20 and $0.3 \%$ rabbit serum in PBS and cut into $3 \mathrm{~mm}$ wide strips. Each strip was incubated with one of the purified MAbs (1:100 dilution) before incubation with the peroxidase-conjugated rabbit anti-mouse antibody (1:2000). Finally, the nitrocellulose strips were treated with ECL detection reagents (Amersham), dried, and exposed to X-ray AGFA film.

Production of anti-VHSV gpG polyclonal antibodies in mice. To increase the probability of obtaining a high titre of VHSV neutralizing antibodies, different antigenic preparations were used. Each female BALB/c mouse was first injected with $20 \mu \mathrm{g}$ of purified gpGs or purified $1 \%$ formalin/ $1 \mathrm{~h}$ treated gpGs (Bachmann et al. 1993) in Freund's complete adjuvant. Then 4 injections given monthly with the same antigens in Freund's incomplete adjuvant were carried out. Alternatively, $20 \mu \mathrm{g}$ of purified VHSV was mixed with $20 \mu \mathrm{g}$ of saponin (Superfos, Vedbaek, Denmark), sonicated and injected per mouse, for 4 mo with monthly injections, and then, to increase the anti-gpG immune response, $20 \mu \mathrm{g}$ of gpG4 in Freund's was given to each mouse for 3 more months.

To obtain $\sim 40 \mathrm{ml}$ of pooled diluted ascites, $3 \mathrm{immu}-$ nized mice per antigen were intraperitoneally injected with 0.5 to $2 \times 10^{6}$ viable myeloma X63/Ag8653 cells per mouse. Mice ascites was then obtained by injection of physiological saline a few days later and pooled as described in Coll (1989). Such ascites contained 20 to $80 \%$ of the serum antibody concentration. The pooled ascites was clarified by low speed centrifugation and stored at $-40^{\circ} \mathrm{C}$ until use. The pooled ascites was passed throughout a $3 \times 10 \mathrm{~cm}$ Sepharose column (Pharmacia) with bound Escherichia coli protein extract $\left(\sim 10 \mathrm{mg} \mathrm{ml}^{-1}\right)$ and rabbit serum $\left(\sim 10 \mathrm{mg} \mathrm{ml}^{-1}\right)$ to adsorb background antibodies. The immunoglobulin $\mathrm{G}$ (IgG) from the adsorbed pooled ascites was then purified by affinity chromatography over protA-Sepharose columns (Pharmacia, Uppsala, Sweden) adjusted to $1.5 \mathrm{M}$ glycine, $3 \mathrm{M} \mathrm{NaCl}$, pH 8.9. The retained IgG was eluted with $50 \mathrm{mM}$ ethylenediamine $\mathrm{pH} 11$ and immediately neutralized with $3 \mathrm{M}$ Tris, $\mathrm{pH}$ 3.5. Eluted fractions were pooled and dialyzed against $10 \mathrm{mM}$ sodium phosphate, $150 \mathrm{mM} \mathrm{NaCl}, \mathrm{pH} 7.2$ (PBS). Purity as tested by gel electrophoresis gave 2 single Coomassie blue stained bands at 50 and $24 \mathrm{kDa}$, respectively.

Production of anti-VHSV polyclonal antibodies in trout. Trout (T1) of $500 \mathrm{~g}$ were injected intraperitoneally 3 times with $30 \mu \mathrm{g}$ of sucrose-gradient purified VHSV, reference strain DK-F1 passed 254 times in cell culture until loss of pathogenicity. The fish were bled 1 mo after the last injection and the sera were freeze dried in $0.4 \mathrm{ml}$ aliquots (kindly provided by N. J. Olesen). Trout (T3) were also injected 4 times over 3 mo with $30 \mu \mathrm{g}$ of heat-killed $\left(37^{\circ} \mathrm{C}, 30 \mathrm{~min}\right)$ PEGconcentrated VHSV 07-71 mixed 1:1 with complete Freund's adjuvant for the first injection and mixed 1:1 with incomplete Freund's for the remaining injections ( $200 \mu \mathrm{l}$ of total volume per trout per injection).

To generate survivors of VHSV infections, about 400 trout weighing between 0.5 and $2 \mathrm{~g}$ were infected by bath for $2 \mathrm{~h}$ at 12 to $14^{\circ} \mathrm{C}$ with $10^{6} \mathrm{TCID}_{50} \mathrm{ml}^{-1}$ of VHSV 07.71 attenuated by 10 passages on EPC cells (Basurco \& Coll 1992). After 1 mo, survival was between 10 and $30 \%$ ( 4 experiments). The trout surviving the infection were challenged 1 to 3 mo later with low passage VHSV 07.71 isolated on EPC cells from infected trout $\left(10^{6} \mathrm{TCID}_{50} \mathrm{ml}^{-1}\right.$, for $2 \mathrm{~h}$ at 10 to $\left.11^{\circ} \mathrm{C}\right)$. After $1 \mathrm{mo}$, between 50 and $80 \%$ (4 experiments) of the trout had survived this second infection (De Kinkelin 1988) and had no signs of haemorrhagic septicaemia. At 2 to 4 mo after the last VHSV challenge, when the fish weighed 100 to $200 \mathrm{~g}$ each and when the frequency of trout with detectable anti-VHSV antibodies has been described to be the highest (Enzmann \& Konrad 1993), the fish were bled and serum samples kept at $-20^{\circ} \mathrm{C}$ (T3). 
As control sera 3 pools were obtained, from 17 healthy noninfected trout of 20 to $500 \mathrm{~g}$ body weight from different farms (T4), from 4 healthy noninfected trout of $20 \mathrm{~g}$ body weight maintained in the laboratory (T5) and from a large batch of pooled serum from about 200 trout of 100 to $200 \mathrm{~g}$ body weight obtained from a farm with no previous history of VHSV infections (Vistahermosa, León, Spain) (T6). Pools were used to minimize the effect of a few possible positive fish.

Indirect ELISA. Polystyrene plates (Dynatech, Plochingen, Germany) were coated with 300 to $1000 \mathrm{pmol}$ peptides well ${ }^{-1}$ or $1 \mu \mathrm{g}$ purified VHSV well ${ }^{-1}$ in $100 \mu \mathrm{I}$ of distilled water, incubated overnight at $37^{\circ} \mathrm{C}$ to dryness, and kept sealed with blue silica gel at $4^{\circ} \mathrm{C}$. The PAbs and MAbs were diluted in dilution buffer $\left(130 \mathrm{mM} \mathrm{NaCl}, 2 \mathrm{mM} \mathrm{KCl}, 8 \mathrm{mM} \mathrm{Na}_{2} \mathrm{HPO}_{4}, 1.4 \mathrm{mM}\right.$ $\mathrm{KH}_{2} \mathrm{PO}_{4}, 0.24 \mathrm{mM}$ merthiolate, $5 \mathrm{~g} \mathrm{l}^{-\mathrm{t}}$ bovine serum albumin, $0.3 \%$ rabbit serum, $0.5 \mathrm{~g} \mathrm{l}^{-1}$ Tween $20,50 \mathrm{mg}$ $\mathrm{l}^{-1}$ phenol red, pH 6.8) and incubated overnight at $4^{\circ} \mathrm{C}$. Preliminary experiments showed that both inclusion of rabbit serum in the dilution buffers and in the blocking step and overnight incubation of the diluted Abs with the dilution buffers reduced nonspecific reactivities. The plates were blocked by incubation for 15 min with dilution buffer. After blocking, the plates were incubated for $60 \mathrm{~min}$ at room temperature with $100 \mu \mathrm{l}$ well ${ }^{-1}$ of the diluted PAbs or MAbs and washed once with distilled water. To detect trout PAbs, the MAb anti-trout IgM 1 G7 (Sanchez et al. 1991) was incubated for $30 \mathrm{~min}$ at room temperature and washed once with distilled water. Peroxidase-labelled rabbit anti-mouse IgG (Nordic, Tilburg, The Netherlands) 100-fold diluted with dilution buffer was added $\left(100 \mu \mathrm{l}\right.$ well $\left.{ }^{-1}\right)$, incubated for $30 \mathrm{~min}$ and then washed 3 times with distilled water. For color development, $50 \mu$ l of substrate buffer $\left(150 \mathrm{mM}\right.$ sodium citrate, $3 \mathrm{mM} \mathrm{H}_{2} \mathrm{O}_{2}$ and $1 \mathrm{mg}$ $\mathrm{l}^{-1}$ o-phenylenediamine, $\mathrm{pH} 4.8$ ) was pipetted per well and the reaction stopped with $50 \mu$ l well ${ }^{-1}$ of $4 \mathrm{M}$ $\mathrm{H}_{2} \mathrm{SO}_{4}$ after $30 \mathrm{~min}$. The results were read in a Titertek Multiskan RC at wavelengths of 492 and $620 \mathrm{~nm}$. The absorbance at $620 \mathrm{~nm}$ was used to correct for individual nonsignificant differences between wells.

Neutralization assays. About $10^{3} \mathrm{TCID}_{50} \mathrm{ml}^{-1}$ of VHSV 07.71 was incubated overnight at $4^{\circ} \mathrm{C}$ with serial dilutions of anti-VHSV antibodies (Lorenzo et al. 1996). Then $100 \mu l$ of the different virus/antibody mixtures was added to cultures of EPC cells in 96-well plates, adsorbed for $2 \mathrm{~h}$ at $14^{\circ} \mathrm{C}$, washed with cell culture medium (RPMI containing $2 \%$ of FCS), filled with $100 \mu \mathrm{l} \mathrm{well} \mathrm{w}^{-1}$ of cell culture medium and incubated overnight at $14^{\circ} \mathrm{C}$. The VHSV-infected EPC monolayers were fixed for $10 \mathrm{~min}$ in cold methanol and dried. To detect the $\mathrm{N}$ antigen of VHSV, the MAb $2 \mathrm{C} 9$ 1000-fold diluted in ELISA dilution buffer was added to the wells $\left(100 \mu \mathrm{l}\right.$ well $\left.{ }^{-1}\right)$ and incubated for $1 \mathrm{~h}$. After washing by immersion in distilled water, $100 \mu \mathrm{l}$ of peroxidase-labelled anti-mouse IgG (Nordic) was added per well and incubation continued for 30 min. After 3 washings by immersion in distilled water, $50 \mu \mathrm{l}$ of $1 \mathrm{mg}$ $\mathrm{ml}^{-1}$ of diaminobenzidine (DAB) (Sigma) in the appropriate buffer was added per well, and the reaction was allowed to proceed until brown foci were detected by inspection with an inverted microscope in the controls containing no antibodies. Once washed with water and air dried, brown foci (DAB positive foci) were counted with an inverted microscope.

Flow cytometry. EPC cultures containing $1 \times 10^{6}$ cells $5 \mathrm{ml}^{-1}$ flask $^{-1}$ were infected at 10 VHSV-07.71 $\mathrm{TCID}_{50} \mathrm{cell}^{-1}$. Noninfected controls were included in every experiment. Incubation was at $14^{\circ} \mathrm{C}$ for $24 \mathrm{~h}$. EPC cells were detached from the surface of the $25 \mathrm{~cm}^{2}$ bottles by mechanical agitation in PBS $(0.15 \mathrm{M}$ sodium chloride, $0.01 \mathrm{M}$ sodium phosphate, $\mathrm{pH} 7.4$ ) containing $1 \%$ BSA, 5 mM EDTA and $0.1 \%$ sodium azide. EPC suspensions were centrifuged at $1200 \times g$ for $10 \mathrm{~min}$ and the pellet was gently resuspended in PBS + BSA + azide containing 50-fold diluted mouse ascites with anti-VHSV antibodies or protein A-purified MAbs adjusted to $1 \mathrm{mg} \mathrm{ml}^{-1}$. After $1 \mathrm{~h}$ at $20^{\circ} \mathrm{C}$ with occasional agitation, the cell suspensions were centrifuged again, washed twice, resuspended in 400 -fold diluted rabbit anti-mouse IgG-FITC conjugate (Nordic) and incubated for $30 \mathrm{~min}$ at $20^{\circ} \mathrm{C}$. The EPC suspensions were again centrifuged and washed twice and then resuspended in PBS $+0.3 \%$ paraformaldehyde. The same day of the harvest and staining, 5000 cells were analysed by flow cytometry in a Beckton-Dickinson (San José, CA) FACScan apparatus using the program LYSYS II version 1.0. Fluorescence was measured at FL1 (514 to $545 \mathrm{~nm}$, green)

\section{RESULTS}

\section{Pepscan mapping with trout sera}

Pooled serum from survivors of VHSV and trout injected with purified VHSV (Fig. 1, T3) and individual serum from trout with high VHSV neutralization titres (Fig. 1, T1 and T2) recognized peptide p106. Furthermore T2 strongly bound p206. Increased reactivity was also seen with other peptides but the levels were comparable to those obtained with pooled sera from trout that had no known contact with VHSV (Fig. 1, T4, T5 and T6). The higher reactivity with p106 appeared to be the major difference between the sera pools from trout previously exposed to VHSV and the sera from trout with no previous contact with VHSV. 

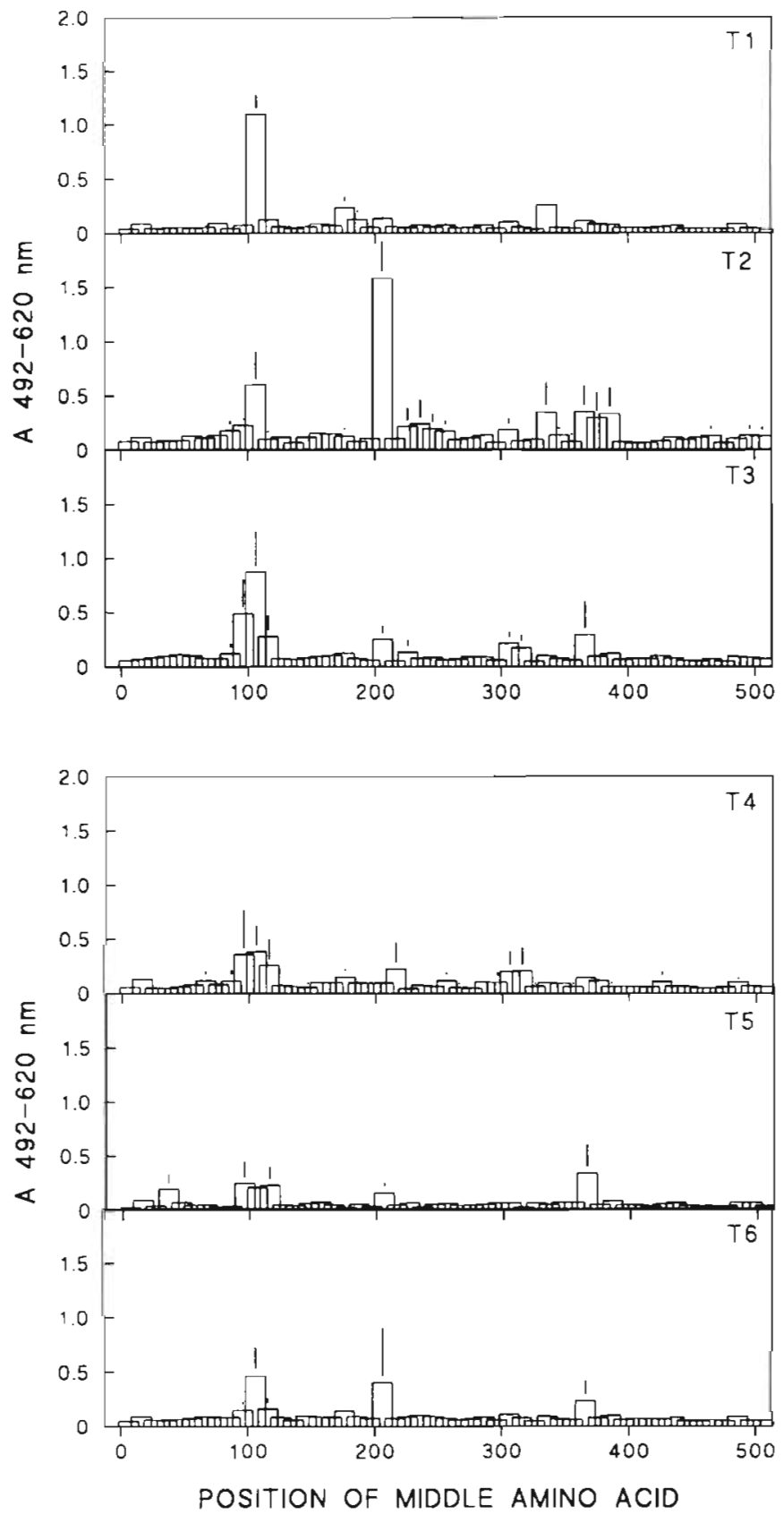

Fig. 1. ELISA reactivity of gpG pepscan with trout serum. Serum from different trout were obtained, pooled, heat inactivated $\left(45^{\circ} \mathrm{C}\right.$ for $\left.30 \mathrm{~min}\right)$ and centrifuged at $5000 \times g$ for $10 \mathrm{~min}$ to eliminate precipitates. Sera supernatants were diluted $1 / 200$ in dilution buffer and ELISA was performed as described. No reaction with the peptides was obtained if the step with the MAb $1 \mathrm{G} 7$ was omitted. T1: serum from a trout injected with sucrose-gradient-purified VHSV with a neutralization titre of 300000 (provided by Dr Olesen); T2: serum from a trout surviving VHSV with a neutralization titre of 100000 (provided by Dr De Kinkelin); T3; pooled serum from 6 trout survivors of VHSV infection plus 3 trout injected with PEG-purified VHSV; T4: pooled serum from 17 noninfected healthy trout from different farms; T5: pooled serum from 4 noninfected healthy trout maintained in the laboratory; T6: pooled serum from $\sim 200$ noninfected healthy trout from 1 farm

\section{Pepscan mapping with mice anti-VHSV PAbs}

Mice were hyperimmunized with purified soluble gpG (gpGs), either fixed with formaldehyde (fgpGs) or native (ngpGs), and with purified VHSV plus recombinant gpG4. Preliminary ELISA experiments showed that the reactivity of the pepscan peptides with the anti-VHSV murine ascites was very low. To obtain measurable absorbance values, IgG had to be isolated and concentrated from the ascites. Relative ELISA titres (measured against pgG4) of anti-VHSV IgG were higher when fgpGs or ngpGs had been used for immunization compared to when VHSV+ gpG4 had been used. However, neutralization titres were higher for ascites obtained by using VHSV+ gpG4 than for ascites obtained by using gpGs as antigen (Table 1).

When the anti-VHSV IgG obtained when using ngpGs and VHSV+gpG4 were tested against the gpG pepscan, the most antigenic peptides were p96, p106, the region from $\mathrm{p} 176$ to $\mathrm{p} 236, \mathrm{p} 306$ and the region from p366 to p386 (Fig. 2). Most of these regions could also be detected by using fixed gpGs (Fig, 2, fGs) but with more difficulties since the overall reaction with most of the peptides seems to be unspecifically increased. The synthetic peptides covering the signal sequence (aa 6-26) and the transmembrane region (aa 462-482) absent from both gpG antigens (gpGs and gpG4) show the estimated average level of background $(<0,2)$. The results obtained with $\mathrm{MAb}$ $1 \mathrm{G} 7$ (anti-trout IgM) obtained and processed in the same way as the other PAbs did not show any absorbance value $\geq 0.15$ for any of the peptides of the pepscan.

\section{Pepscan mapping with anti-gpG MAbs}

The antigenicity of the pepscan peptides was further studied with anti-gpG MAbs (Table 2) by ELISA. I10 reacted with p146 whereas IP1H3 reacted with p406 (Fig. 3). The results obtained with the pepscan for MAbs I10 and IP1H3 were confirmed by Western blot using truncated recombinant $9 p G$ fusion proteins. MAb I10 bound the gpG fragment including aa 17-191, whereas MAb IP1H3 recognized fragments including aa 360-474 and aa 153-474 (Fig. 4). The results obtained with MAb I10 were further confirmed by ELISA using other synthetic peptides. Thus whereas I10 showed positive reaction with p4 (aa 122-151), it did not show any reaction with p2 (aa 82-109) or with p3 (aa 110-121) (not shown). Other MAbs (Table 2) did not show any reactivity in the pepscan (not shown). 
Table 1 Relative titres of anti-VHSV gpG murine PAbs. IgG from mice ascites was isolated by prot-A affinity chromatography and concentrated to $1 \mathrm{mg} \mathrm{ml}^{-1}$ of protein. ELISA titre was then tested against purified VHSV and defined as the absorbance at $492 \mathrm{~nm}\left(A_{492 \mathrm{~nm}}\right)$ per $\mu \mathrm{g}$ of protein as calculated from the linear part of the absorbance/dilution curve. Neutralization titre was defined as the inverse of the concentration of IgG necessary to reduce to $50 \%$ the number of VHSV-infected foci. Averages from duplicates are shown. gpGs: glycoprotein G isolated from the supernatant of VHSVinfected EPC (s: soluble). ngpGs: native gpGs. fgpGs: formaldehyde-fixed gpGs

\begin{tabular}{|llcc|}
\hline Antigen & Adjuvant & $\begin{array}{c}\text { ELISA titre } \\
\left(A_{492 \mathrm{~nm}}{\left.\mu g^{-1} \text { protein }\right)}\right.\end{array}$ & $\begin{array}{c}\text { Neutralization } \\
\left.\text { titre }(1 / \mu \mathrm{g} \mathrm{m})^{-1}\right)\end{array}$ \\
\hline VHSV+gpG4 & Saponine & $0.11 \pm 0.03$ & $0.51 \pm 0.32$ \\
ngpGs & Freund's & $0.40 \pm 0.05$ & $0.014 \pm 0.001$ \\
fgpGs & Freund's & $0.36 \pm 0.12$ & $0.012 \pm 0.001$ \\
\hline
\end{tabular}

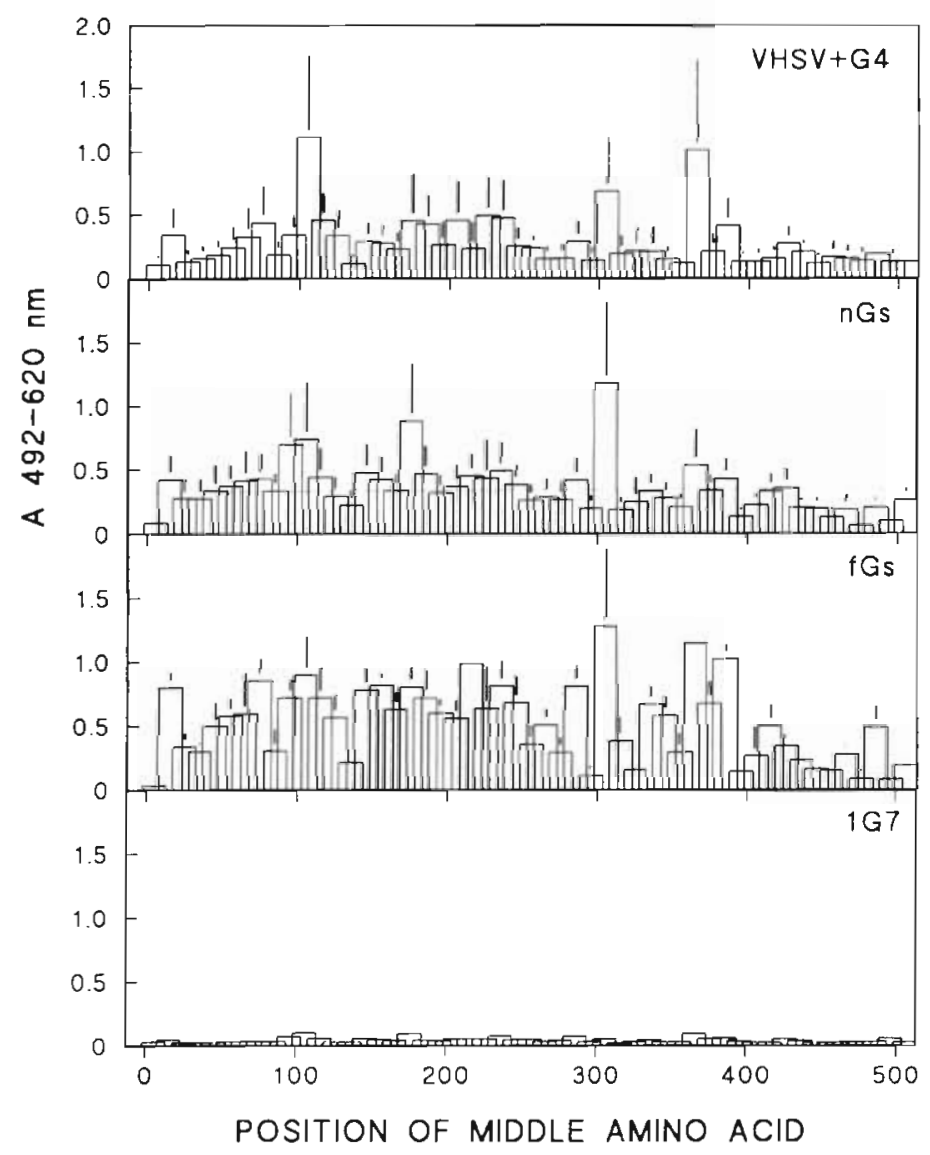

Fig. 2. ELISA reactivity of gpG pepscan with mice anti-G PAbs. 15-mer peptides from the gpG of VHSV in solid phase were incubated with $15 \mu \mathrm{g} \mathrm{ml}^{-1}$ (except fGs which was $5 \mu \mathrm{g}$ $\mathrm{ml}^{-1}$ ) of purfied IgG obtained from mice ascites containing anti-gpG PAbs. fGs: ascites from mice immunized with fixed Gs with Freund's adjuvant; $n$ Gis: ascites from mice immunized with native Gs with Freund's adjuvant; VHSV + G4: ascites from mice immunized with purfied VHSV and G4 with saponine adjuvant; $1 \mathrm{G} 7 \mathrm{IgG}$ : isolated from mice ascites containing anti-trout IgM MAb 1 G7 (Sanchez et al. 1991) used as a control. Means and standard deviations from 3 different experiments are represented

\section{Flow cytometry of VHSV-infected cells with anti-gpG MAbs}

Flow cytometry with VHSV-infected EPC cells showed that the 2 non-neutralizing pepscan-positive MAbs I10 and IP1H3 were unable to stain the surface of infected cells, suggesting that the epitopes they recognize are not available when the $\mathrm{gpG}$ is native and situated on the surface of the infected cells. In contrast, neutralizing pepscannegative MAbs $1 \mathrm{H} 10, \mathrm{C} 10$ and $3 \mathrm{~F} 1 \mathrm{~A} 2$ were capable of staining the surface of VHSVinfected EPC cells, indicating that the epitopes recognized by these MAbs are exposed on the surface of the membranes of VHSV-infected cells (Fig. 5).

\section{DISCUSSION}

The mapping of linear epitopes recognized by antiVHSV PAbs obtained from trout and/or mice indicates

Table 2. Properties of the MAbs against the gpG of VHSV in this work. "MAbs obtained with the myeloma SP2. The rest were obtained with the myeloma line X63-Ag8.653. MAbs were obtained in ascites and protein A purified as described in the 'Materials and methods'. ELISA titre was defined as the inverse of the dilution of the MAb that yields an $O D_{(492 \mathrm{~nm})}$ more than 2 -fold over the background. $\%$ neutralization $=100$ - (number of foci with the MAb - background)/(number foci in control - background $\times 100 .(+)$ Positive result, $(-)$ negative result. nd: not determined. To obtain the \% of neutralization shown in the table, MAbs $\mathrm{C} 10$ and $3 \mathrm{~F} 1 \mathrm{~A} 2$ were used at $1 \mu \mathrm{g}$

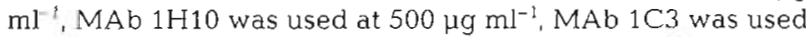
at $65 \mu \mathrm{g} \mathrm{ml}^{-1}$ and MAb $4 \mathrm{E} 6$ was used at $10 \mathrm{\mu g} \mathrm{ml}^{-1}$ The following MAbs had been described previously: I10 (Mourton et al. 1990), IP1H3 (Lorenzen et al. 1990), 1H10 (Sanz \& Coll 1992), and C10 (Mourton et al. 1990)

\begin{tabular}{|c|c|c|c|c|c|c|}
\hline Name & (Isotype) & $\begin{array}{c}\text { ELISA } \\
\text { G4 }\end{array}$ & $\begin{array}{l}\text { ELISA } \\
\text { VHSV }\end{array}$ & $\begin{array}{l}\text { Blot } \\
\text { G4 }\end{array}$ & FACS & $\begin{array}{l}\% \text { neutral } \\
\text { ization }\end{array}$ \\
\hline 110 & $(-)$ & $>1000$ & $>1000$ & + & nd & - \\
\hline IP1H3 & $(\lg G 1)$ & $>1000$ & $>1000$ & + & nd & - \\
\hline 1. $\mathrm{H} 10$ & (nd) & $>1000$ & $>1000$ & + & + & 80 \\
\hline C10 & $(\operatorname{Ig} G 2 a)$ & 20 & 120 & - & + & 100 \\
\hline 3FIA2 & $(\lg G 1)$ & 20 & 120 & - & + & 100 \\
\hline $1 \mathrm{C} 3$ & (lgG1) & 500 & 2500 & - & - & 77 \\
\hline $1 \mathrm{G} 2$ & (nd) & 100 & 20 & + & - & - \\
\hline $1 G 5$ & (IgG2a) & 1.00 & 20 & - & - & -. \\
\hline 2D1 & $(\lg G 2 a)$ & 100 & - & + & - & - \\
\hline $2 \mathrm{G} 4^{\circ}$ & (nd) & 20 & - & - & - & - \\
\hline $3 \mathrm{~B} 8^{\circ}$ & (nd) & 20 & - & - & - & - \\
\hline $3 \subset 12^{\circ}$ & (nd) & 20 & - & - & - & - \\
\hline $3 F 4$ & (nd) & 20 & - & - & - & - \\
\hline $4 B 10^{\circ}$ & (IgG3) & 500 & 2500 & - & - & - \\
\hline $4 \mathrm{E} 5^{\circ}$ & (IgG2a) & 20 & - & - & - & - \\
\hline $4 \mathrm{E} 6^{\circ}$ & $(\lg M)$ & 20 & - & - & + & 36 \\
\hline $4 \mathrm{EF}^{\circ}$ & (nd) & 100 & - & - & - & - \\
\hline
\end{tabular}




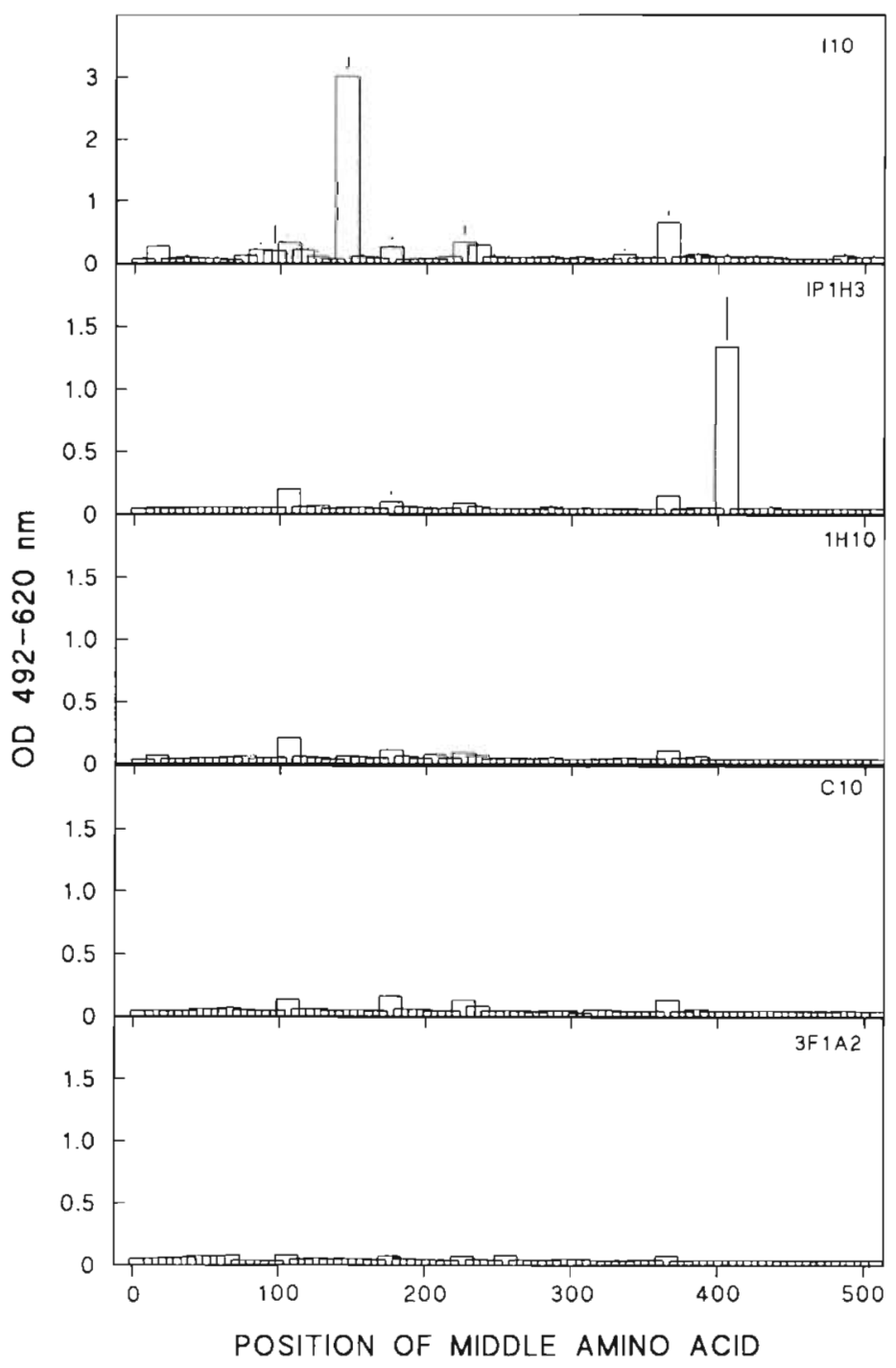

Fig. 3. ELISA reactivity of gpG pepscan with anti-gpG MAbs. 15-mer peptides from the gpG of VHSV in solid phase were incubated with purified IgG isolated from murine ascites containing anti-gpG MAbs. Means and standard deviations from 2 different experiments are shown. MAbs were 110 and $\mathrm{C} 10$ (Mourton et al. 1990), IP1H3 (Lorenzen et al. 1990), 1H10 (Sanz \& Coll 1992, Sanz et al. 1993) and 3F1A2 (Lorenzen unpubl.). MAbs $1 \mathrm{H} 10, \mathrm{C} 10$ and 3F1A2 were neutralizing Similar results to those obtained with MAbs $1 \mathrm{H} 10, \mathrm{C} 10$ and 3FIA2 were obtained with other MAbs (Table 2)

the presence of at least 2 regions in the gpG of VHSV which map outside the mutant aa positions identified by the sequencing of MAR mutants (Bearzotti et al. 1995). The region situated around p106 appears antigenic not only using mice PAbs but also with trout PAbs (Figs. 1 \& 2). This region contained the amino heptad repeat region which was the highest phosphatidylserine binding region of VHSV (Estepa \& Coll 1996) and including some trout leucocyte stimulating sequences (Lorenzo et al. 1995). The other antigenic

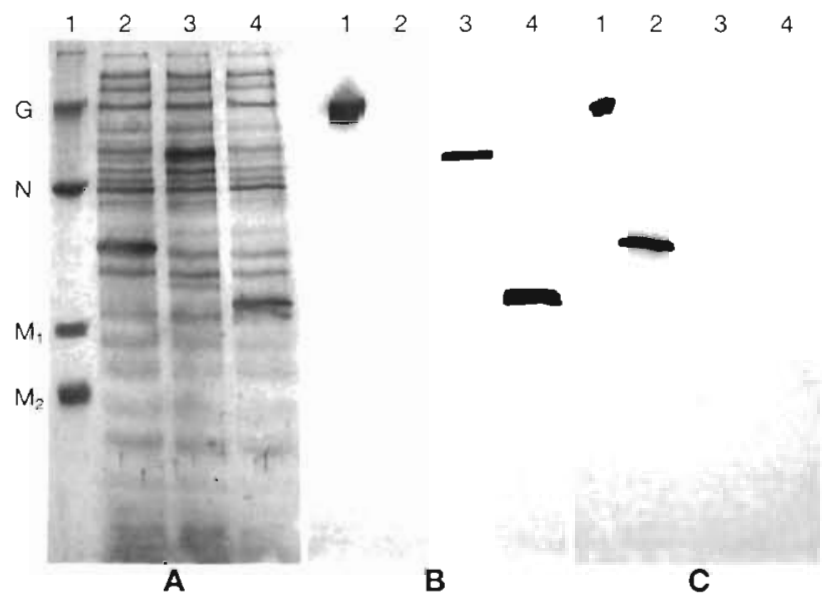

Fig. 4. Immunoblotting reactivity of MAbs with truncated VHSV gpG expressed in E. coli. G $(67 \mathrm{kD}), \mathrm{N}(41 \mathrm{kD}), \mathrm{M}_{1}$ $(28 \mathrm{kD}), \mathrm{M}_{2}(24 \mathrm{kD})$, VHSV proteins on the left-hand side. Lanes 1 . purified VHSV; lanes 2 to 4 : $E$. coli cell extract containing fusion proteins including aa 17-191 (lanes 2), 153-474 (lanes 3) and 360-474 (lanes 4) of the gpG. A: stained with colloidal gold for total protein. B: immunostained with $\mathrm{MAb}$ IP1H3. C: immunostained with MAb I10

region situated between aa 300 and 400 contained the other 2 heptad repeats of VHSV, some lower phosphatidylserine binding stretches (Estepa \& Coll 1996) and another leucocyte stimulating peptide (p306) present in $41.6 \%$ of an outbred trout population (Lorenzo et al. 1995). Nevertheless, by performing the pepscan assays in solid phase rather than in solution because of practical feasibility, we have probably bypassed some possible reactivities. All of this study is thus restricted by the methodology used and no claims of exclusivity can be made.

It is not surprising that serum from trout that have no previous contact with VHSV gave some positive reactions in the pepscan (Fig. 1, T4, T5 and T6) because it is well known that trout serum tend to bind nonspecifically to many surfaces and/or proteins (Olesen et al. 1991, Sanchez et al. 1993). On the other hand, the possibility cannot be excluded that a few trout included in those uninfected control trout pools might have survived a previous unnoticed VHS disease. Further studies including higher numbers of immunized and nonimmunized fish are needed to analyze this variability.

Of all the 17 anti-VHSV G MAbs tested in this work, only MAbs I10 (aa 139-153) and IP1H3 (aa 399-413) bound peptides on the pepscan and were positive in immunoblotting. The immunoblot data thus supported the more precise epitope localizations obtained by pepscan but it cannot be taken as indicative of a positive reaction in the pepscan ELISA since MAbs $1 \mathrm{G} 2$ and 2D1 also recognize gpG4 in blotting yet they were still negative in the pepscan ELISA, most probably due to their low titre (Table 2). 

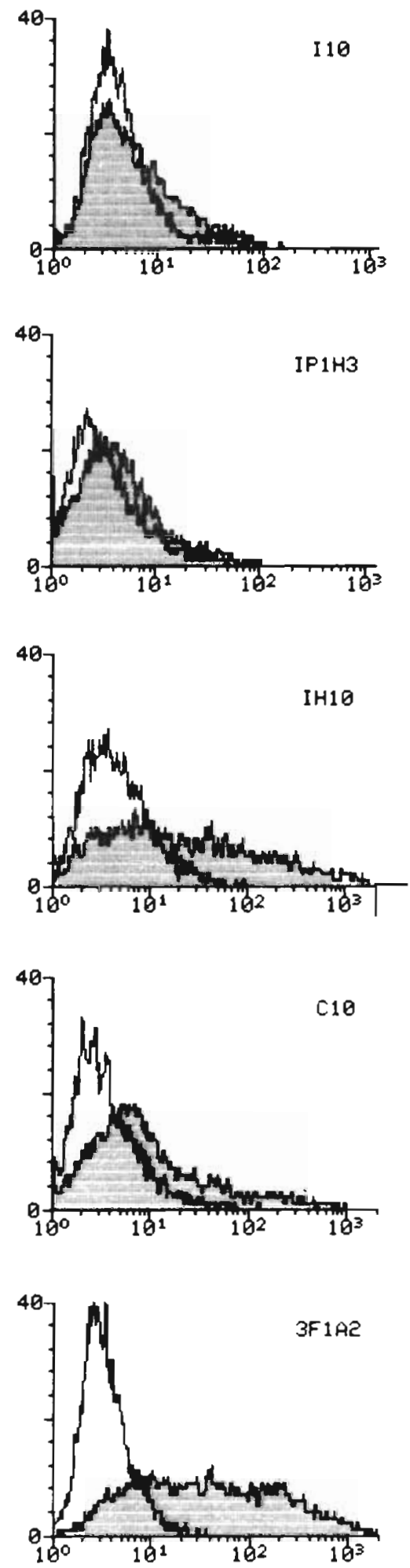

Fig. 5. Fluorescence at 515 to $545 \mathrm{~nm}$ measured by flow cytometry of VHSV-infected EPC cells stained with MAbs antiVHSV I10, IP1H3,1H10, C10 and 3F1A2. Fluorescence intensity ( $x$-axis) versus number of cells ( $y$-axis), $x$ and $y$ axes are in relative units. Shadowed profile: VHSV-infected EPC cells: open profile: noninfected EPC cells
MAbs I10 and IP1H3 did not react by FACS with VHSV-infected cells. However, there was no VHSVneutralizing activity associated with these MAbs. This result could mean that 110 and IP1H3 were unable to bind to the native gpG, indicating that such epitopes were only accessible to the denatured protein and that, in the membrane of the infected cells, these sites of the gpG could thus be buried (as suggested by the flow cytometry results). In contrast, neutralizing MAbs do bind to the gpG exposed in the membranes of VHSVinfected cells (immunofluorescence positives) but do not bind to the peptides in the pepscan.

The epitopes recognized by 110 and IP1H3 are probably of lineal nature, in contrast to the epitopes recognized by the other gpG MAbs found negative in the pepscan. MAb C10 MAR mutants showed the simultaneous occurrence of at least 2 mutations (most of them at aa 140 and 433) that also appeared in attenuated variants (Bearzotti et al. 1995). It is noteworthy that both of these 2 positions map outside the VHSV epitopes defined in this work by pepscan. However, this result also suggests the conformational nature of that domain. Should these observations be generalized as more results are provided or more MAbs become available, it would suggest the complementarity of both strategies to define antibody epitopes in the $\mathrm{gpG}$ of VHSV as has been shown in rabies (Lafay et al 1996). Complex discontinuous antigenic epitopes involved in VHSV neutralization could be mapped by the MAR mutant strategy whereas linear epitopes could be mapped with the pepscan or similar strategies. Because antigenic regions other than those involved in neutralization in vitro could be of importance during in vivo protection, as demonstrated for rabies (LeFrancois 1984) and for VHSV (Lorenzen et al. 1990), the identification of linear epitopes could also be of importance for the design of subunit vaccines.

Acknowledgements. Thanks are due to Dr P. De Kinkelin for the MAb I10 and the trout serum T2, to Dr N. J. Olesen for the trout serum T1 and to J. P. Coll for typing. Dr M. Etzerodt is thanked for technical advice on the truncated gpG gene constructs. This work was supported by Research Grants CT94-1334 from the AIR2 Program of the European Economic Community, from INIA project SC94-102, Spain, from CICYT projects AGF95-910 and AGF97-297, Spain, and from the Danish Biotechnology Research Program. L.P. was recipient of a contract from the Spanish Ministerio de Educación y Ciencia/INIA. M.F. was a recipient of a fellowship from Gobierno Vasco.

\section{LITERATURE CITED}

Bachmann MF, Künding TM, Kalberer CP. Hengartner $H$, Zinkernagel RM (1993) Formalin inactivation of vesicular stomatitis virus impairs T-cell- but not T-help-independent B-cell responses. J Virol 67:3917-3922 
Basurco B, Coll JM (1992) In vitro studies and in vivo immunization with the first viral haemorrhagic septicaemia viruses isolated in Spain compared to international reference serotypes. Res Vet Sci 53:93-97

Basurco B, Sanz F, Marcotegui MA, Coll JM (1991) The free nucleocapsids of the viral ha emorrhagic septicaemia virus contain two antigenically related nucleoproteins. Arch Virol 119:153-163

Bearzotti M, Monnier AF, Vende P, Grosclaude J, De Kinkelin $P$, Benmansour A (1995) The glycoprotein of viral haemorrhagic septicaemia virus (VHSV): antigenicity and role in virulence. Vet Res 26:413-422

Benmansour $\mathrm{H}$, Leblois $\mathrm{H}$, Coulon P, Tuffereau C, Gaudin Y, Flamand A, Lafay $F$ (1991) Antigenicity of rabies virus glycoprotein. J Virol 65:4198-4203

Christensen $\mathrm{JH}$, Hansen PK, Lillelund $\mathrm{O}$, Thogersen $\mathrm{HC}$ (1991) Sequence-specific binding of the $\mathrm{N}$-terminal threefinger fragment of Xenopus transcription factor IIIA to the internal control region of a \% RNA gene. FEBS Lett 281: $181-184$

Coll JM (1989) Injection of physiological saline facilitates recovery of ascitic fluids for antibody production. J Immunol Meth 104:219-222

De Kinkelin P (1988) Vaccination against viral haemorrhagic septicaemia. In: Ellis AE (ed) Fish vaccination. Academic Press, New York, p 172-192

Enzmann H, Konrad M (1993) Longevity of antibodies in brown trout and rainbow trout following experimental infection with VHS virus. Bull Eur Assoc Fish Pathol 13: 193-194

Estepa A, Coll JM (1996) Pepscan mapping and fusion related properties of the major phosphatidylserine-binding domain of the glycoprotein of viral haemorrhagic septicaemia virus, a salmonid rhabdovirus. Virology 216:60-70

Estepa A, Thiry M, Coll JM (1994) Recombinant protein fragments from haemorrhagic septicaemia rhabdovirus stimulate trout leucocyte anamnestic in vitro responses. J Gen Virol 75:1329-1338

Grigera PR, Keil W, Wagner RR (1992) Disulphide-bonded discontinuous epitopes on the glycoprotein of vesicular stomatitis virus (New Jersey serotype). J Virol 66: $3749-3757$

Huang C, Chien MS, Landolt M, Batts W, Winton J (1996) Mapping the neutralizing epitopes on the glycoprotein of infectious haematopoietic necrosis virus, a fish rhabdovirus. J Gen Virol 77:3033-3040

Keil W, Wagner RR (1989) Epitope mapping by deletion mutants and chimeras of two vesicular stomatitis virus glycoprotein genes expressed by a vaccinia virus vector Virology 170:392-407

Kim CH, Winton JR, Leong JC (1994) Neutralization-resistant variants of infectious hematopoietic virus have altered virulence and tissue tropism. J Virol 68:8447-8453

Lafay F, Benmansour A, Chebli K, Flamand A (1996) Immunodominant epitopes defined by a yeast-expressed library of random fragments of the rabies virus glycoprotein map outside major antigenic sites. J Gen Virol 77:339-346

LeBerre M, De Kinkelin P, Metzger A (1977) Identification sérologique des rhabdovirus des salmonides. Bull Off Int Epiz 87:391-393

Lecocq-Xhonneux F, Thiry M, Dheur I, Rossius M, Vanderheijden N, Martial J, De Kinkelin P (1994) A recombinant viral haemorrhagic septicaemia virus glycoprotein expressed in insect cells induces protective immunity in rainbow trout. J Gen Virol 75:1579-1587

LeFrancois L (1984) Protection against lethal viral infection by neutralizing and nonneutralizing monoclonal antibodies: distinct mechanisms action in vivo. J Virol 51:208-214

LeFrancois L, Lyles DS (1982) The interaction of antibody with the major surface glycoprotein of vesicular stomatitis virus. Il. Monoclonal antibody to nonneutralizing and crossreactive epitopes of Indiana and New Jersey serotypes. Virology 121:168-174

Leong JC, Bootland L, Anderson E, Chiou PW, Drolet B, Kim C, Lorz H, Mourich D, Ormonde P, Perez L, Trobridge G (1995) Viral vaccines for aquaculture. J Mar Biotechnol 3: $16-23$

Lorenzen N, Olesen NJ (1997) Immunization with viral antigens: viral haemorrhagic septicaemia. Dev Biol Stand 90:201-209

Lorenzen N, Olesen NJ, Jargensen PEV (1988) Production and characterization of monoclonal antibodies to four Egtved virus structural proteins. Dis Aquat Org 4:35-42

Lorenzen N, Olesen NJ, Vestergaard-Jørgensen PE (1990) Neutralization of Egtved virus pathogenicity to cell cultures and fish by monoclonal antibodies to the viral G protein. J Gen Virol 71:561-567

Lorenzo GA, Estepa A. Chilmonczyk S, Coll JM (1995) Different peptides from haemorrhagic septicaemia rhabdoviral proteins stimulate leucocyte proliferation with individual fish variation. Virology 212:348-355

Lorenzo GA, Estepa A, Coll JM (1996) Fast neutralization/ immunoperoxidase assay for viral haemorrhagic septicaemia with anti-nucleoprotein monoclonal antibody. J Virol Meth 58:1-6

Luo L. Li Y, Snyder RM, Wagner RR (1988) Point mutations in the glycoprotein gene of vesicular stomatitis virus (New Jersey serotype) selected by resistance to neutralization by epitope-specific monoclonal antibodies. Virology 163 : $341-348$

Mourton C, Bearzotti M, Piechaczyk M, Paolucci F, Pau B, Bastide JM, Kinkelin PD (1990) Antigen-capture ELISA for viral haemorrhagic septicaemia virus serotype I. J Virol Meth 29:325-334

Ni Y. Tominaga Y, Honda Y, Morimoto K, Sakamoto S, Kawai A (1995) Mapping and characterization of a sequential epitope on the rabies virus glycoprotein which is recognized by a neutralizing monoclonal antibody, RG719. Microbiol Immunol 39:693-702

Noonan B, Enzmann PJ, Trust TJ (1995) Recombinant infectious necrosis virus and viral haemorrhagic septicaemia virus glycoprotein epitopes expressed in Aeromonas salmonicida induce protective immunity in rainbow trout (Oncorhynchus mykiss). Appl Environ Microbiol 61. $3586-3591$

Olesen NJ, Lorenzen N, Vestergaard-Jørgensen PE (1991) Detection of rainbow trout antibody to Egtved virus by enzyme-linked immunosorbent assay (ELISA), immunofluorescence (IF), and plaque neutralization tests $150 \%$ PNT). Dis Aquat Org 10:31-38

Perez L, Estepa A, Coll JM (1998) Purification of the glycoprotein G from VHSV, a fish rhabdovirus, by lectin affinity chromatography. J Virol Meth (in press)

Raux $H$, Coulon P, Lafay F, Flamand A (1995) Monoclonal antibodies which recognize the acidic configuration of the rabies glycoprotein at the surface of the virion can be neutralizing. Virology 210:400-408

Sanchez C, Coll JM, Dominguez J (1991) One step purification of rainbow trout immunoglobulin. Vet Immunol Immunopathol 27:383-392

Sanchez C, Babin M, Tomillo J, Obeira FM, Dominguez J (1993) Quantification of low levels of rainbow trout immunoglobulin by enzyme immunoassay using two monoclonal antibodies. Vet Immunol Immunopathol 36:64-74 
Sanz F, Coll JM (1992) Neutralizing-enhancing monoclonal antibody recognizes the denatured glycoprotein of viral haemorrhagic septicaemia virus. Arch Virol 127(1-4): $223-232$

Sanz F, Basurco B, Babin M. Dominguez J, Coll JM (1993) Monoclonal antibodies against the structural proteins of viral haemorrhagic septicaemia virus isolates. J Fish Dis $16: 53-63$

Thiry $M$, Lecocq-Xhonneux F, Dheur I, Renard A, De Kinkelin P (1991) Sequence of a cDNA carrying the glycoprotein gene and part of the matrix protein M2 gene of viral haemorrhagic septicaemia virus, a fish rhabdovirus. Bio-

Editorial responsibility: Jo-Ann Leong.

Corvallis, Oregon, USA chim Biophys Acta 1090:345-347

VanDeerHeijden MHT, Tank MWT, Booms GHR, Bakuwel P, Boon. JH (1993) In vivo lymphocyte stimulation test in European eel (Anguilla anguilla L). Bull Eur Assoc Fish Pathol 13:213-215

Vandepol SB, LeFrancois L, Holland JJ (1986) Sequences of the major antibody binding epitopes of the Indiana serotype of vesicular stomatitis virus. Virology 148:312-325

Volk WA, Snyder RM, Benjamin DC, Wagner R (1982) Monoclonal antibodies to the glycoprotein of vesicular stomatitis virus: comparative neutralizing activity. J Virol 42 $220-227$

Submitted: March 19, 1998; Accepted: Auqust 25, 1998

Proofs received from author(s): November 18, 1998 